\title{
Exploring alternative routes for oxygen administration
}

\author{
Elisa Damiani ${ }^{1,2^{*}}$ D, Alex Dyson ${ }^{2}$, Lucia Zacchetti ${ }^{2,3}$, Abele Donati $^{1}$ and Mervyn Singer ${ }^{2}$
}

\author{
* Correspondence: \\ eli.dam86@alice.it \\ ${ }^{1}$ Anesthesia and Intensive Care Unit, \\ Department of Biomedical Sciences \\ and Public Health, Università \\ Politecnica delle Marche, via Tronto \\ 10/A, 60126 Torrette di Ancona, \\ Italy \\ ${ }^{2}$ Bloomsbury Institute of Intensive \\ Care Medicine, Division of Medicine, \\ University College London, London, \\ UK \\ Full list of author information is \\ available at the end of the article
}

\begin{abstract}
Background: Hypoxemia may compromise cell metabolism and organ function. Supplemental oxygen $\left(\mathrm{O}_{2}\right)$ at high concentrations may prove ineffective, and issues relating to hyperoxia, barotrauma, mechanical ventilation, and extracorporeal oxygenation are well documented. Old reports suggest the potential safety and efficacy of alternative routes for $\mathrm{O}_{2}$ administration, such as intravenous or intestinal. We re-explored these routes in rat models of hypoxemia.

Methods: Hypoxemia was induced in spontaneously breathing, anesthetized rats by breathing a hypoxic gas mix $\left(\mathrm{FiO}_{2}\right.$ 0.1). Pilot studies infusing pure $\mathrm{O}_{2}$ gas caused early death, likely due to pulmonary embolism. Instead, rats ( $n=6 /$ group) were given intravenous $\mathrm{O}_{2}$ via a continuous infusion of pre-oxygenated Hartmann's solution $(10 \mathrm{ml} / \mathrm{kg} / \mathrm{h})$ for $3 \mathrm{~h}$ with normal Ringer's lactate used in control animals. In separate experiments ( $n=8 /$ group), bowel intraluminal oxygenation was assessed with pure $\mathrm{O}_{2}$ administered through a cannula placed into the jejunal lumen at a dose of a $15 \mathrm{ml} / \mathrm{kg}$ bolus followed by a continuous infusion of $50 \mathrm{ml} / \mathrm{kg} / \mathrm{h}$; no treatment was given to controls. Echocardiography, arterial blood gas analysis, mean arterial pressure, muscle and liver $\mathrm{tPO}_{2}$, muscle microvascular perfused vessel density, and urine output were measured.
\end{abstract}

Results: Administration of oxygenated Hartmann's solution $\left(\mathrm{PO}_{2}\right.$ of solution at endexperiment $=87.5 \pm 1.7 \mathrm{kPa}$ ) was safe but did not increase either systemic or tissue oxygenation. Similarly, the administration of bowel $\mathrm{O}_{2}$ was safe but did not improve neither systemic nor liver oxygenation.

Conclusions: In this rat model of hypoxemia, the intravenous infusion of gaseous $\mathrm{O}_{2}$ was unfeasible as it induced early mortality. Although safe, both intravenous infusion of oxygenated Hartmann's solution and bowel $\mathrm{O}_{2}$ administration were unable to improve arterial or tissue oxygenation.

Keywords: Oxygen therapy, Hypoxemia, Tissue oxygenation

\section{Background}

During hypoxemia, the low tissue oxygen $\left(\mathrm{O}_{2}\right)$ supply may compromise cellular aerobic metabolism and determine organ dysfunction. Supplemental $\mathrm{O}_{2}$ at high concentration, with or without supported ventilation, is usually administered for hypoxemic respiratory failure. However, this conventional approach may prove inadequate when gas exchange through the alveolar-capillary membrane is severely impeded, e.g., severe acute respiratory distress syndrome [1]. In addition, adverse effects of excessive inspired $\mathrm{O}_{2}$ administration and mechanical ventilation are well documented, including

(C) 2016 The Author(s). Open Access This article is distributed under the terms of the Creative Commons Attribution 4.0 International License (http://creativecommons.org/licenses/by/4.0/), which permits unrestricted use, distribution, and reproduction in any medium, provided you give appropriate credit to the original author(s) and the source, provide a link to the Creative Commons license, and indicate if changes were made. 
hyperoxia- and ventilator-induced acute lung injury [2]. Extracorporeal membrane oxygenation is an alternative albeit invasive modality that is also associated with a significant complication rate including bleeding, thrombosis, and infection [3].

A century ago, Tunnicliffe and Stebbing reported rapid and safe symptomatic relief of cyanosis in patients following the administration of intravenous $\mathrm{O}_{2}$ gas through a peripheral venous cannula at a rate of $600-1200 \mathrm{ml} / \mathrm{h}$ [4]. The authors did however recommend that "irregularity of the pulse" and "dilatation of the right side of the heart" are indications to stop the gas administration [4]. In 1888, John Harvey Kellogg at the Battle Creek Sanitarium in Michigan showed that $\mathrm{O}_{2}$ may be rapidly absorbed through the intestinal mucosa and encouraged the use of $\mathrm{O}_{2}$ enemata as a remedy for respiratory failure-induced cyanosis and reported several successfully treated cases [5]. These routes for $\mathrm{O}_{2}$ administration warrant re-exploration as potentially easy and cheap alternatives to conventional $\mathrm{O}_{2}$ therapy. We therefore sought to determine the safety and efficacy of intravenous and intestinal $\mathrm{O}_{2}$ administration in a rat model of hypoxemia.

\section{Methods}

All experiments were performed according to Home Office (UK) guidelines under the 1986 Scientific Procedures Act with local (University College London) ethics committee approval (PPL 70/8290). Spontaneously breathing male Wistar rats (300-350 g body weight) were anesthetized by $5 \%$ isoflurane in room air in an induction chamber and then placed on a heated mat to maintain rectal temperature at $37{ }^{\circ} \mathrm{C}$ throughout. Under $2 \%$ isoflurane anesthesia, the left common carotid artery and right internal jugular vein were cannulated. The arterial line was connected to a pressure transducer (Powerlab, AD Instruments, Chalgrove, UK) for continuous monitoring of mean arterial pressure (MAP). A tracheostomy was performed and connected to a T-piece to maintain anesthesia and vary the fraction of inspired $\mathrm{O}_{2}\left(\mathrm{FiO}_{2}\right)$. The bladder was exposed through a small laparotomy and cannulated using a 1.57-mm-OD tubing for drainage and quantification of urine output. A small incision was made on the external side of the right hind limb, and an 18-gauge guidance cannula was used to insert a tissue $\mathrm{O}_{2}$ tension $\left(\mathrm{tPO}_{2}\right.$ ) sensor (Oxylite, Oxford Optronix, Milton Park, Oxon, UK) into the right vastus lateralis muscle [6]. For measurement of liver $\mathrm{tPO}_{2}$, the probe was placed into the airtight space between two of the liver lobes through a small midline laparotomy [6]. To enable microcirculatory assessment, a 2-cm skin incision was performed on the medial side of the left hind limb, and the perimysium was carefully separated from the muscle by blunt dissection in order to minimize tissue damage and bleeding [7].

In 16 animals (bowel $\mathrm{O}_{2}$ model), a 2-cm midline laparotomy was additionally performed to allow insertion of an 18-gauge cannula into the jejunum to which it was secured by a suture. The cannula was exteriorized to enable injection of $\mathrm{O}_{2}$, and the abdomen was closed with sutures. After instrumentation, isoflurane was reduced to $1.2 \%$ for the remainder of the experiment. Euvolemia was obtained by intravenous administration of $4 \mathrm{ml} / \mathrm{kg}$ Hartmann's solution followed by a continuous infusion of $10 \mathrm{ml} / \mathrm{kg} / \mathrm{h}$. The animals were allowed to stabilize for $60 \mathrm{~min}$ before baseline measurements were taken. The $\mathrm{FiO}_{2}$ was then reduced to 0.1 and maintained until the end of the experiment to induce hypoxemia. At the end of the study, the animals were sacrificed without regaining consciousness. 


\section{Model 1: intravenous $\mathrm{O}_{2}$ administration}

Pilot studies were performed to construct a model of intravenous administration of gaseous $\mathrm{O}_{2}$. The infusion of pure $\mathrm{O}_{2}$ gas at a slow rate of $2 \mathrm{ml} / \mathrm{kg} / \mathrm{h}$ (approximately $0.67 \mathrm{ml} / \mathrm{h}$ ) resulted in death within minutes. The demise was preceded by a sharp fall in MAP and dilatation of the right ventricle evidenced by echocardiography, suggesting acute heart failure due to pulmonary embolism. Therefore, this technique was abandoned.

As an alternative, oxygenated Hartmann's solution was prepared by bubbling pure $\mathrm{O}_{2}$ gas into a bag of Hartmann's solution until the fluid was fully saturated. An $\mathrm{O}_{2}$ tension $\left(\mathrm{PO}_{2}\right)$ of $100 \mathrm{kPa}$ within the solution was confirmed by gas analysis (ABL625 blood gas analyzer, Radiometer, Copenhagen, Denmark). The $\mathrm{PO}_{2}$ of the solution was re-assessed at endexperiment. After $60 \mathrm{~min}$ of hypoxemia, animals ( $n=6$ /group) were randomized to receive a continuous infusion of $10 \mathrm{ml} / \mathrm{kg} / \mathrm{h}$ of oxygenated Hartmann's solution (IV-O $\mathrm{O}_{2}$ group) or an equal volume of normal, non-oxygenated Hartmann's solution (control group) over the following $3 \mathrm{~h}$. Measurements were taken at baseline and at hourly intervals for $4 \mathrm{~h}$.

\section{Model 2: bowel $\mathrm{O}_{2}$ administration}

After 30 min of hypoxemia, eight animals (bowel $\mathrm{O}_{2}$ group) received an injection of $15 \mathrm{ml} /$ $\mathrm{kg}$ of pure $\mathrm{O}_{2}$ gas into the jejunal lumen, followed by continuous administration at a rate of $50 \mathrm{ml} / \mathrm{kg} / \mathrm{h}$ for $90 \mathrm{~min}$. These volumes were determined in pilot studies as the maximum volumes not producing any signs of intestinal over-distension or ischemia. No oxygen treatment was administered to a control group $(n=8)$. Measurements were taken at baseline and at 30-min intervals for $120 \mathrm{~min}$. Five animals per group were monitored for a further $2 \mathrm{~h}$.

\section{Measurements}

Echocardiography (Vivid 7, GE Healthcare, Bedford, UK) was performed to assess stroke volume (SV), heart rate (HR), and respiratory rate (RR). SV was calculated from the flow-velocity integral measured in the ascending aorta (assuming an aortic annulus radius of $1.4 \mathrm{~mm}$ [6]) by pulsed-wave Doppler. Arterial and venous blood samples (about $0.2 \mathrm{ml}$ ) were collected in heparinized capillary tubes for blood gas analyses (ABL625 analyzer), which included measurements of arterial base excess (ABE) and lactate. Cumulative urine output was measured at $120 \mathrm{~min}$ (bowel $\mathrm{O}_{2}$ model) and at the end of the experiment. Muscle and liver $\mathrm{tPO}_{2}$ were assessed using large-area-surface $\mathrm{O}_{2}$ sensors (0.7-mm diameter) connected to an Oxylite tissue monitoring system, as described previously [7]. The skeletal muscle microcirculation was evaluated with sidestream dark field videomicroscopy (Microscan, Microvision Medical, Amsterdam, NL), which enables real-time in vivo visualization of blood flow in microvascular beds [8]. Videos from five adjacent sites were recorded with adequate contrast, focus, and stability; an absence of pressure artifact was defined by preservation of venular perfusion. The perfused vessel density (PVD), representing the total length of vessels with a continuous/sluggish flow divided by the total surface of the image, was calculated offline using AVA 3.0 (Automated Vascular Analysis) software (MicroVision Medical) [9].

\section{Statistics}

Statistical analysis was performed using Graph Pad version 5 (GraphPad Software, La Jolla, CA, USA). Normality of distribution was checked using the Kolmogorov-Smirnov 
test. Data are expressed as mean \pm standard error or median [first to third quartile], as appropriate. Statistics on parametric data were performed using repeated measures two-way analysis of variance followed by Bonferroni's post hoc test. Non-parametric data were analyzed using the Friedman test with Dunn's post hoc test for multiple comparisons and the Mann-Whitney $U$ test. A $p$ value $<0.05$ was used to indicate statistical significance.

\section{Results}

Model 1: intravenous $\mathrm{O}_{2}$ administration

All animals survived until the end of the 4-h experiment. At baseline, no statistically significant differences were observed between the two groups in any of the variables measured. After $1 \mathrm{~h}$ of breathing $10 \% \mathrm{O}_{2}$, similar reductions in arterial $\mathrm{PO}_{2}$, arterial and venous $\mathrm{O}_{2}$ saturation $\left(\mathrm{SO}_{2}\right)$, and tissue $\mathrm{PO}_{2}$ in the muscle and liver were observed in the two groups (Fig. 1). A similar decrease in MAP was observed in the two groups $(p<0.001$ versus baseline). HR and SV tended to decrease and increase, respectively. Arterial lactate levels were significantly elevated at $60 \mathrm{~min}$ in both groups while $\mathrm{ABE}$ tended to decrease (Fig. 1). Respiratory rate tended to be elevated in both groups during hypoxia, leading to a significant reduction in arterial carbon dioxide tension $\left(\mathrm{PCO}_{2}\right)$ and increase in $\mathrm{pH}$ (Table 1).

The administration of oxygenated Hartmann's solution $\left(\mathrm{PO}_{2}\right.$ of solution at endexperiment $=87.5 \pm 1.7 \mathrm{kPa}$ ) did not yield any significant improvement in blood or tissue oxygenation (Fig. 1). Respiratory alkalosis persisted until the end of the experiment in both groups (Table 1).

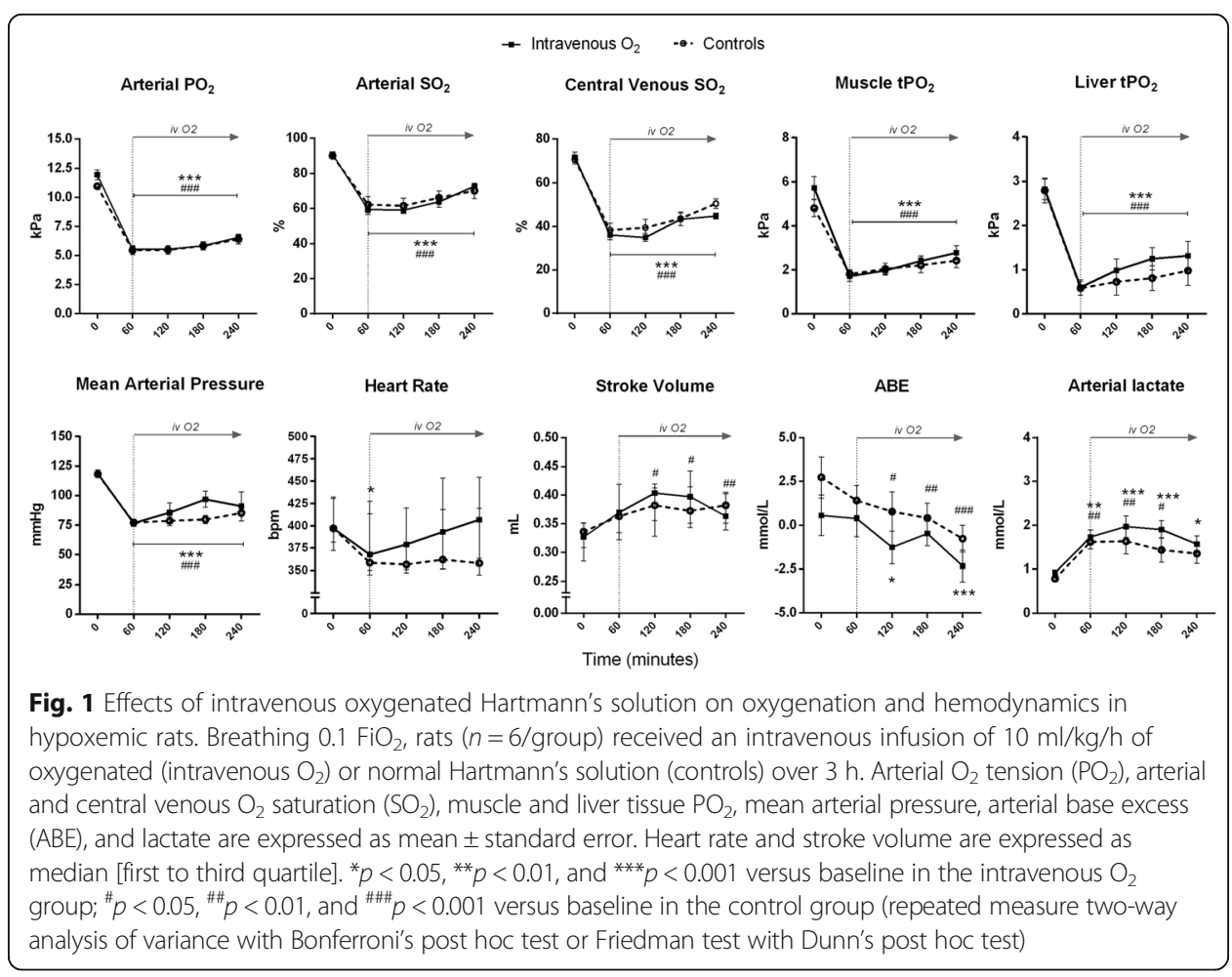


Table 1 Respiratory and microcirculatory data for model 1 (intravenous $\mathrm{O}_{2}$ administration)

\begin{tabular}{|c|c|c|c|c|c|}
\hline & Baseline & $60 \mathrm{~min}$ & $120 \mathrm{~min}$ & $180 \mathrm{~min}$ & $240 \mathrm{~min}$ \\
\hline \multicolumn{6}{|c|}{ Respiratory rate $(n / \mathrm{min})$} \\
\hline $\mathrm{IV}-\mathrm{O}_{2}$ & $65[62-73]$ & $71[69-77]$ & $75[71-83]^{*}$ & $75[71-81]^{*}$ & $72[69-79]$ \\
\hline Controls & 77 [60-89] & 83 [67-96] & 81 [69-94] & 85 [69-93] & 84 [69-97] \\
\hline \multicolumn{6}{|l|}{$\mathrm{PaCO}_{2}(\mathrm{kPa})$} \\
\hline $\mathrm{IV}-\mathrm{O}_{2}$ & $4.8 \pm 0.1$ & $3.8 \pm 0.1^{* *}$ & $3.5 \pm 0.1^{* *}$ & $3.5 \pm 0.1^{* *}$ & $3.3 \pm 0.1^{* *}$ \\
\hline Controls & $4.8 \pm 0.1$ & $3.5 \pm 0.1^{* *}$ & $3.4 \pm 0.2^{* *}$ & $3.2 \pm 0.1^{* *}$ & $3.1 \pm 0.1^{* *}$ \\
\hline \multicolumn{6}{|l|}{$\mathrm{pH}$} \\
\hline $\mathrm{IV}-\mathrm{O}_{2}$ & $7.44 \pm 0.01$ & $7.52 \pm 0.01^{* *}$ & $7.53 \pm 0.01^{* *}$ & $7.53 \pm 0.02^{* *}$ & $7.53 \pm 0.02^{* *}$ \\
\hline Controls & $7.47 \pm 0.01$ & $7.55 \pm 0.01^{* *}$ & $7.56 \pm 0.01^{* *}$ & $7.57 \pm 0.01^{* *}$ & $7.57 \pm 0.01^{* *}$ \\
\hline \multicolumn{6}{|c|}{ Perfused vessel density $\left(\mathrm{mm} / \mathrm{mm}^{2}\right)$} \\
\hline $\mathrm{IV}-\mathrm{O}_{2}$ & $17.0 \pm 0.7$ & $19.5 \pm 1.0^{* * *}$ & $18.5 \pm 0.6$ & $18.6 \pm 0.4$ & $18.5 \pm 0.8$ \\
\hline Controls & $20.9 \pm 0.7$ & $24.6 \pm 2.1$ & $21.8 \pm 1.0$ & $20.8 \pm 1.7$ & $20.2 \pm 0.9$ \\
\hline
\end{tabular}

A non-significant increase in microcirculatory PVD was observed at $60 \mathrm{~min}$ in both groups (Table 1). No significant differences were found between the two groups throughout the experiment, apart from a lower value at $60 \mathrm{~min}$ in the $\mathrm{IV}-\mathrm{O}_{2}$ groups as compared to controls ( $p=0.011$, Table 1$)$.

Cumulative urine output at $240 \mathrm{~min}$ did not differ between the two groups (6.5 [5.5-18.9] $\mathrm{ml} / \mathrm{kg}$ in the IV- $\mathrm{O}_{2}$ group and 5.8 [4.9-6.4] $\mathrm{ml} / \mathrm{kg}$ in controls, $p=0.238$ ).

\section{Model 2: bowel $\mathrm{O}_{2}$ administration}

All animals survived until the end of the experiment. At baseline, no statistically significant differences were observed between the two groups in any of the variables measured. After 30 min of breathing $10 \% \mathrm{O}_{2}$, similar changes in arterial $\mathrm{PO}_{2}$, arterial and venous $\mathrm{SO}_{2}$, and $\mathrm{tPO}_{2}$ in the muscle and liver were observed in the two groups (Fig. 2). MAP was significantly reduced in both groups $(p<0.001$ versus baseline); HR tended to decrease while SV tended to increase (Fig. 2). Arterial lactate levels were elevated in both groups ( $p<0.01$ versus baseline) while $\mathrm{ABE}$ was significantly reduced only in the bowel $\mathrm{O}_{2}$ group ( $p=0.012$ versus baseline) (Fig. 2). Respiratory rate increased following hypoxemia in both groups, leading to respiratory alkalosis (Table 2).

The administration of $\mathrm{O}_{2}$ into the jejunal lumen did not produce any significant difference in any of the respiratory or hemodynamic variables measured over the course of the experiment. No differences were found between bowel $\mathrm{O}_{2}$ and control groups at any time points (Fig. 2). Arterial lactate levels decreased during bowel $\mathrm{O}_{2}$ administration ( $p=0.22$ versus baseline at $120 \mathrm{~min}$ ) but rose again over the following $2 \mathrm{~h}$ once the oxygen was discontinued ( $p=0.06$ versus baseline at $240 \mathrm{~min}$ ). Arterial $\mathrm{PCO}_{2}$ and $\mathrm{pH}$ remained significantly altered throughout the experiment in both groups but did not differ between the groups (Table 2).

Microcirculatory PVD did not change significantly following hypoxemia and no differences were found between the groups at any time points (Table 2).

Cumulative urine output was similar between the two groups at $120 \mathrm{~min}$ (3.4 [2.8-6.4] $\mathrm{ml} / \mathrm{kg}$ in the bowel $\mathrm{O}_{2}$ group and $3.1[2.3-6.0] \mathrm{ml} / \mathrm{kg}$ in controls, $p=0.32$, 


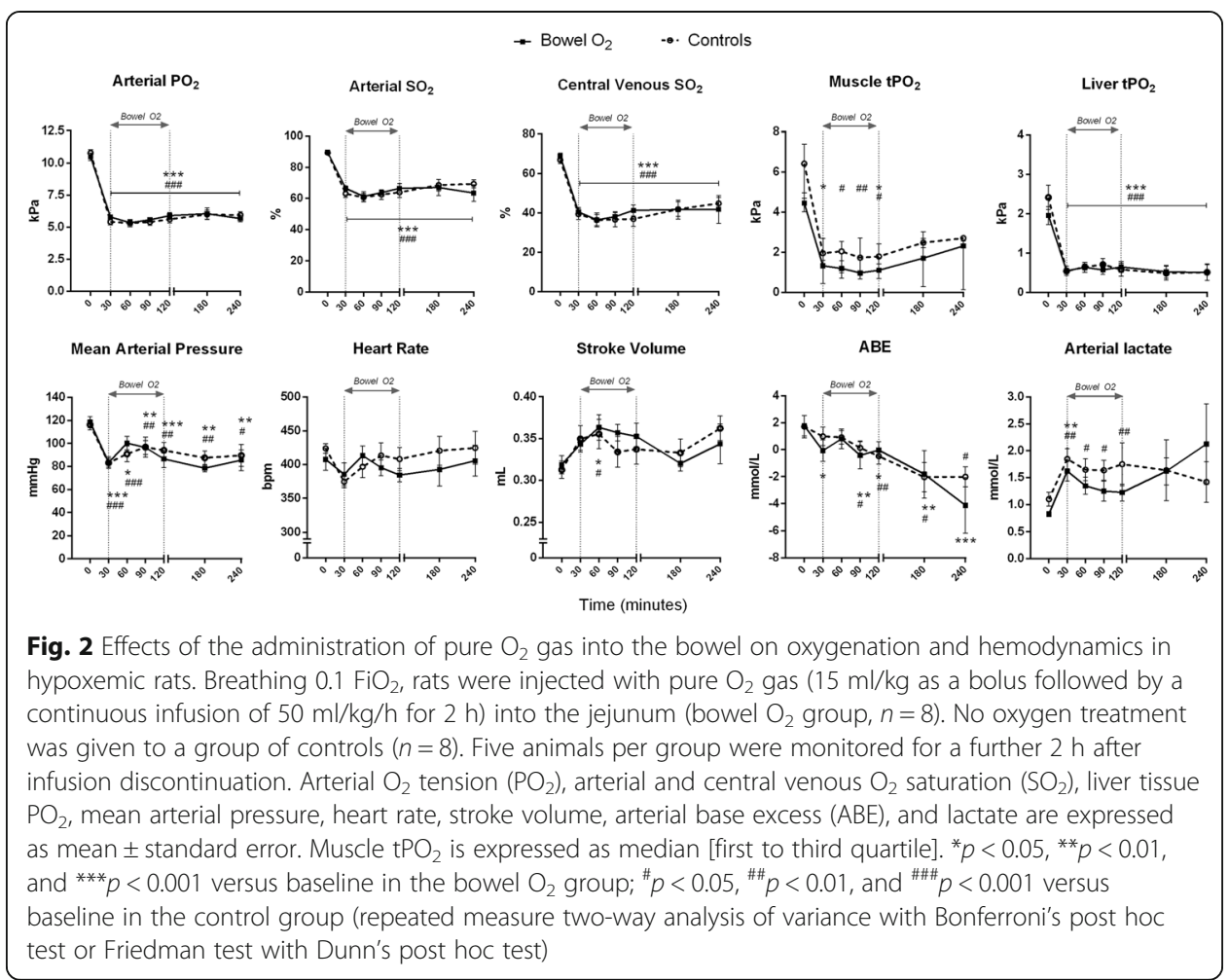

$n=8 /$ group $)$ and $240 \mathrm{~min}\left(7.0\right.$ [6.1-13.1] $\mathrm{ml} / \mathrm{kg}$ in the bowel $\mathrm{O}_{2}$ group and 6.4 [5.8-12.0] $\mathrm{ml} / \mathrm{kg}$ in controls, $p=0.53, n=5 /$ group).

\section{Discussion}

In our rat model of hypoxemia, the infusion of pure $\mathrm{O}_{2}$ gas through a central vein was unfeasible as it induced early death due to pulmonary embolism. The infusion of oxygenated Hartmann' solution over $3 \mathrm{~h}$ was safe; however, it proved ineffective in increasing blood or tissue oxygenation. Similarly, the administration of gaseous $\mathrm{O}_{2}$ into the

Table 2 Respiratory and microcirculatory data for model 2 (bowel $\mathrm{O}_{2}$ administration)

\begin{tabular}{|c|c|c|c|c|}
\hline & Baseline & $30 \mathrm{~min}$ & $120 \mathrm{~min}$ & $240 \mathrm{~min}$ \\
\hline \multicolumn{5}{|c|}{ Respiratory rate $(n / \mathrm{min})$} \\
\hline Bowel- $\mathrm{O}_{2}$ & $70 \pm 3$ & $81 \pm 3^{*}$ & $81 \pm 3^{*}$ & $82 \pm 2^{*}$ \\
\hline Controls & $69 \pm 4$ & $83 \pm 4^{* *}$ & $86 \pm 5^{* * *}$ & $81 \pm 7^{* *}$ \\
\hline \multicolumn{5}{|l|}{$\mathrm{PaCO}_{2}(\mathrm{kPa})$} \\
\hline Bowel- $\mathrm{O}_{2}$ & $4.7 \pm 0.1$ & $3.5 \pm 0.1^{* * *}$ & $3.4 \pm 0.1^{* * *}$ & $2.8 \pm 0.2^{* * *}$ \\
\hline Controls & $4.7 \pm 0.2$ & $3.5 \pm 0.1^{* * *}$ & $3.2 \pm 0.1^{* * *}$ & $2.8 \pm 0.1^{* * *}$ \\
\hline \multicolumn{5}{|l|}{$\mathrm{pH}$} \\
\hline Bowel- $\mathrm{O}_{2}$ & $7.47 \pm 0.01$ & $7.54 \pm 0.01^{* * *}$ & $7.57 \pm 0.01^{* * *}$ & $7.53 \pm 0.04^{* * *}$ \\
\hline Controls & $7.47 \pm 0.01$ & $7.55 \pm 0.01^{* * *}$ & $7.56 \pm 0.01^{* * *}$ & $7.58 \pm 0.01^{* * *}$ \\
\hline \multicolumn{5}{|c|}{ Perfused vessel density $\left(\mathrm{mm} / \mathrm{mm}^{2}\right)$} \\
\hline Bowel- $\mathrm{O}_{2}$ & $20.8[14.9-21.1]$ & $21.2[17.7-23.1]$ & $21.0[18.6-22.1]$ & $18.5[17.1-19.5]$ \\
\hline Controls & $19.9[18.2-23.3]$ & $20.0[18.1-23.8]$ & $18.0[16.5-22.0]$ & $17.9[15.7-18.7]$ \\
\hline
\end{tabular}

${ }^{*} p<0.05 ;{ }^{* *} p<0.01 ;{ }^{* * *} p<0.001$ versus baseline 
small bowel did not produce any improvement in oxygenation although it was not associated with any unfavorable effects.

Numerous attempts have been made in the past to oxygenate the blood by routes other than the lung. Nysten was probably the first to inject gaseous $\mathrm{O}_{2}$ into the veins of a living animal in 1811 [10]. The first administration to a human being dates back to 1902, when Mariani reported an improved pulse and respiration following the infusion of $120 \mathrm{ml} \mathrm{O} \mathrm{O}_{2}$ over 15 min through the dorsalis pedis vein in a patient with tuberculosis, but who died the next day [11]. Several other investigators reported encouraging results in both animals and humans $[4,12-14]$; however, these data were not confirmed by others. It became clear that the intravenous administration of pure $\mathrm{O}_{2}$ gas could lead to pulmonary embolism and worsened blood oxygenation $[15,16]$. It was also suggested that only a small amount of the gas injected could be absorbed as only a minimal surface of gas was in direct contact with the blood due to the coalescence of gas bubbles [16]. Our study in hypoxemic rats supports the lack of safety of intravenous gas infusion. We used an $\mathrm{O}_{2}$ infusion rate of $2 \mathrm{ml} / \mathrm{kg} / \mathrm{h}$, which would correspond to an infusion rate of $140 \mathrm{ml} / \mathrm{h}$ for a human weighing $70 \mathrm{~kg}$. There are case reports showing that the intravenous bolus injection of $100 \mathrm{ml}$ of air can cause cardiac arrest due to fatal pulmonary embolism [17]. Other authors suggest the lethal dose for humans to be $3-5 \mathrm{ml} / \mathrm{kg}$ and that a rapid injection of $300-500 \mathrm{ml}$ at a rate of $100 \mathrm{ml} / \mathrm{s}$ is fatal [18]. A larger amount of $\mathrm{O}_{2}$ may be potentially administered in humans or large animals using peripheral venous accesses and lower rates of infusion without hemodynamic or respiratory sequelae. However, scientific evidences for this are lacking, and the questions as to whether a sufficient volume of gas could be administered safely and absorbed to effectively improve tissue oxygenation remain unanswered.

Despite being safe, the intravenous infusion of oxygenated Hartmann's solution was not able to induce any increase in blood or tissue $\mathrm{PO}_{2}$. In an experimental study in normoxemic rabbits, Kim et al. reported an increase in arterial $\mathrm{PO}_{2}$ during the administration of oxygenated Ringer's lactate through a central vein [19]. However, spontaneous variation cannot be excluded as no control group was used in this study. The $\mathrm{PO}_{2}$ of solution at end-experiment in our study was even higher $(87.5 \pm 1.7 \mathrm{kPa})$ than that reported by Kim et al. $(76.7 \mathrm{kPa})$; however, it must still be acknowledged that the amount of $\mathrm{O}_{2}$ dissolved remains small. In our experiments, at 60 min hypoxemia, the average $\mathrm{O}_{2}$ delivery $\left(\mathrm{DO}_{2}\right)$ was $14.4 \pm 2.6 \mathrm{ml} / \mathrm{min}$ (as calculated from the cardiac output, $\mathrm{Hb}$ levels, $\mathrm{SaO}_{2}$, and $\mathrm{PaO}_{2}$ ) and the $\mathrm{O}_{2}$ consumption $\left(\mathrm{VO}_{2}\right)$ was $5.9 \pm 1.2 \mathrm{ml} / \mathrm{min}$ (as calculated from the cardiac output and the difference between the arterial and venous $\mathrm{O}_{2}$ content). According to the Henry's law and the ideal gas law, at $\mathrm{PO}_{2}=100 \mathrm{kPa}$ and temperature $=20{ }^{\circ} \mathrm{C}$, we can estimate that the amount of $\mathrm{O}_{2}$ dissolved in the oxygenated Hartmann' solution was about $0.03127 \mathrm{ml} \mathrm{O}_{2} / \mathrm{ml}$. At a fluid infusion rate of $10 \mathrm{ml} / \mathrm{kg} / \mathrm{h}$, a rat weighing $300 \mathrm{~g}$ received around $0.05 \mathrm{ml} / \mathrm{min}(3 \mathrm{ml} / \mathrm{h})$ of Hartmann' solution, containing $0.0016 \mathrm{ml} \mathrm{O} / 2 \mathrm{~min}$. This represents about the $0.01 \%$ of the total $\mathrm{DO}_{2}$ and the $0.027 \%$ of the total $\mathrm{VO}_{2}$, thus making an insignificant contribution to systemic oxygenation.

In a guinea pig experiment, Kellogg noted that the dark blood in the portal veins assumed a bright red color soon after the injection of $\mathrm{O}_{2}$ into the rectum, suggesting a rapid absorption through the intestinal wall [5]. In a case series, Maruzok et al. reported a significant increase in the $\mathrm{PaO}_{2} / \mathrm{FiO}_{2}$ ratio in patients with acute respiratory 
distress syndrome following the intestinal insufflation of pure $\mathrm{O}_{2}$ gas through a nasointestinal tube [20]. As the improvement in systemic oxygenation lasted for more than $32 \mathrm{~h}$, direct intestinal absorption of $\mathrm{O}_{2}$ seemed unlikely [20]. Again, the lack of a control group prevents definitive conclusions from being drawn. In our study in hypoxemic rats, the administration of pure $\mathrm{O}_{2}$ gas into the small bowel was unable to produce any increase in systemic oxygenation, either rapidly (during infusion) or in the $2 \mathrm{~h}$ following infusion discontinuation. The liver should have been the first organ to benefit from an intestinal absorption of $\mathrm{O}_{2}$ into the portal veins for anatomical reasons. The observed trend towards a reduction in arterial lactate levels during the administration of bowel $\mathrm{O}_{2}$ might reflect an improved hepatic metabolism. However, no improvement was seen in liver $\mathrm{tPO}_{2}$ during or after the insufflation of $\mathrm{O}_{2}$ into the bowel. By administering a $5-\mathrm{ml}$ bolus of pure $\mathrm{O}_{2}$ followed by a continuous infusion of $50 \mathrm{ml} / \mathrm{kg} / \mathrm{h}$, we infused a total of $27.5 \mathrm{ml}$ of pure $\mathrm{O}_{2}$ for a rat weighing $300 \mathrm{~g}(5 \mathrm{ml}+15 \mathrm{ml} / \mathrm{h}$ over $90 \mathrm{~min}$ ). Even if all this $\mathrm{O}_{2}$ had been absorbed in the circulating blood over time, this would have contributed to systemic oxygenation only by about $2 \%$ of the systemic $\mathrm{DO}_{2}$ (total $\mathrm{DO}_{2}$ over 90 min under $\mathrm{FiO}_{2} \quad 10 \%=1296 \mathrm{ml}$ ) and $4.2 \%$ of systemic $\mathrm{VO}_{2}$ (total $\mathrm{VO}_{2}$ over 90 min under $\mathrm{FiO}_{2} 10 \%=531 \mathrm{ml}$ ). Our results do not show any evidence supporting the ability of $\mathrm{O}_{2}$ to be absorbed in a detectable amount through the intestinal mucosa into the blood.

Other alternatives to pulmonary oxygenation have been explored over the past years. Perfluorocarbon-based $\mathrm{O}_{2}$ carriers have been tested using several routes of administration, including intravenous [21], transintestinal [22], and transpleural [23], as well as for liquid ventilation [24]. Nevertheless, none of these agents has been approved for clinical use due to storage, production, and clinical evaluation complications [25]. Kheir et al. manufactured lipid-based $\mathrm{O}_{2}$-carrying microbubbles for intravenous infusion that could rescue hypoxemia in asphyxiated rabbits, decreasing the incidence of cardiac arrest and organ injury without inducing any signs of pulmonary embolism [26]. The administration of phospholipid-coated $\mathrm{O}_{2}$ microbubbles into the peritoneal cavity was effective in increasing systemic oxygenation in animal models of pneumothorax [27] and asphyxia [28]. The research for simple, non-invasive, and cheap alternatives to pulmonary oxygenation is still ongoing, and further studies are encouraged.

Some limitations of our study need to be acknowledged. Firstly, retrospective theoretical calculations of the amount of $\mathrm{O}_{2}$ administered in the different models clearly show that the experimental approach applied was unsuitable to produce any positive results. However, we designed our experiments based on previously published reports $[4,5,10-16,19,20]$ that represented our proof of concept. Secondly, we constructed an artificial short-term model of hypoxemia by administering a hypoxic gas mixture. Other experimental models of acute respiratory distress syndrome (e.g., by repeated pulmonary lavage [29]) could more closely reproduce the clinical scenario. However, our method allowed a better control of the amount of $\mathrm{O}_{2}$ absorbed in the lungs, thus limiting variability in oxygenation parameters. Other potential routes for $\mathrm{O}_{2}$ administration were not evaluated, such as the peritoneal route. Mechanical ventilation of the peritoneal cavity was able to improve oxygenation in an experimental model of acute respiratory syndrome in rabbits, inducing both an increase in arterial $\mathrm{PO}_{2}$ and a decrease in arterial $\mathrm{PCO}_{2}$ [30]. 


\section{Conclusions}

In hypoxemic rats, the infusion of $2 \mathrm{ml} / \mathrm{kg} / \mathrm{h}$ of pure $\mathrm{O}_{2}$ gas into a central vein induced early death due to pulmonary embolism. However, both the intravenous infusion of oxygenated Hartmann's solution and the administration of gaseous $\mathrm{O}_{2}$ into the small bowel were safe but ineffective in increasing blood or tissue oxygenation. Our study suggests the inadequacy of intravenous oxygenated fluids or intestinal insufflation of $\mathrm{O}_{2}$ as alternative ways for $\mathrm{O}_{2}$ administration in rats.

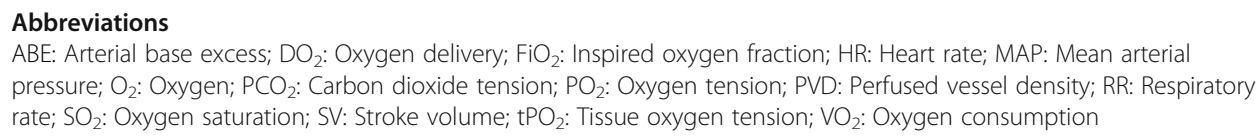

\section{Authors' contributions}

ED designed the study, performed the experiments, analyzed the data, and drafted the manuscript. ADy and LZ performed the experiments and contributed to the interpretation of the data. ADo contributed to the analysis of the data and interpretation of the results and revised the manuscript. MS designed the study, supervised the experiments, interpreted the data, and revised the manuscript. All authors read and approved the final version of the manuscript. All authors are accountable for all aspects of the work in ensuring that questions related to the accuracy or integrity of any of its parts are appropriately investigated and resolved.

\section{Competing interests}

The authors declare that they have no competing interests.

\section{Author details}

${ }^{1}$ Anesthesia and Intensive Care Unit, Department of Biomedical Sciences and Public Health, Università Politecnica delle Marche, via Tronto 10/A, 60126 Torrette di Ancona, Italy. ${ }^{2}$ Bloomsbury Institute of Intensive Care Medicine, Division of Medicine, University College London, London, UK. ${ }^{3}$ Department of Anesthesiology and Intensive Care, Fondazione IRCCS, Cà-Granda Ospedale Maggiore Policlinico, Milan, Italy.

Received: 9 September 2016 Accepted: 5 October 2016

Published online: 10 October 2016

\section{References}

1. Pipeling MR, Fan E (2010) Therapies for refractory hypoxemia in acute respiratory distress syndrome. JAMA 304(22):2521-2527

2. Budinger GRS, Mutlu GM (2013) Balancing the risks and benefits of oxygen therapy in critically ill adults. Chest 143(4):1151-1162

3. Ventetuolo CE, Muratore CS (2014) Extracorporeal life support in critically ill adults. Am J Resp Crit Care Med 190(5):497-508

4. Tunnicliffe FW, Stebbing GF (1916) The intravenous injection of oxygen gas as a therapeutic measure. Lancet 188: $321-323$

5. Kellogg JH (1888) Oxygen enemata as a remedy in certain diseases of the liver and intestinal tract. JAMA XI 8: 258-262

6. Slama M, Susic D, Varagic J, Ahn J, Frohlich ED (2003) Echocardiographic measurement of cardiac output in rats. Am J Physiol Heart Circ Physiol 284:H691-H697

7. Dyson A, Stidwill R, Taylor V, Singer M (2007) Tissue oxygen monitoring in rodent models of shock. Am J Physiol Heart Circ Physiol 293:H526-H533

8. Dyson A, Cone S, Singer M, Ackland GM (2012) Microvascular and macrovascular flow are uncoupled in early polymicrobial sepsis. Br J Anaesth 108:973-978

9. Damiani E, Adrario E, Luchetti MM, Scorcella C, Carsetti A, Mininno N, Pierantozzi S, Principi T, Strovegli D, Bencivenga R, Gabrielli A, Romano R, Pelaia P, Ince C, Donati A (2015) Plasma free hemoglobin and microcirculatory response to fresh or old blood transfusions in sepsis. PLoS One 10(5):e0122655

10. Nysten P (1811) Recherches de Physiologie et de Chemie Pathologique. Paris: J. A. Brosson.

11. Mariani F (1902) Le iniezioni endovenose di ossigeno nell'uomo. Riforma Med 18:194

12. Singh I (1935) Intravenous injection of oxygen with animal under ordinary and increased atmospheric pressure. J Physiol 84:315-322

13. Jacobi M, Klein B, Rascoff H, Kogut B, Auerbach R, Jennings J (1946) Effects of intravenous administration of oxygen on shock in dogs and in human beings. Arch Surg 52:42-49

14. Cone F (1951) Intravenous oxygen. Anesthesiology 12:181-188

15. Weston RE, Karel $L(1947)$ The influence of denitrogenation on the response of anesthetized dogs to intravenously injected oxygen. J Clin Invest 26(5):837-848

16. Sanders JH, Isoe IM (1947) Intravenous oxygen and pulmonary embolism. Ann Surg 126:208-214

17. Harving ML, Lyager A, Sandstrom HR (2014) latrogenic venous air embolism after unintentional injection of atmospheric air during computed tomography. Ugeskr Laeger. 176:V06130407. 
18. Gordy S, Rowell S (2013) Vascular air embolism. Int J Crit IIIn Inj Sci 3:73-76

19. Kim WO, Cho CH (1987) Intravenous oxygenation with lactated Ringer's solution. J Korean Med Sci 2(2):111-115

20. Maruzok V, Belikov VL, Slivin OA (2014) Intestinal insufflation of small volume of oxygen increases systemic oxygenation in acute respiratory distress syndrome patients. Eur J Anaesthesiol 31:1-2

21. Stephan C, Schlawne C, Grass S, Waack IN, Ferenz KB, Bachmann M, Barnert S, Schubert R, Bastmeyer M, de Groot H, Mayer C (2014) Artificial oxygen-carriers based on perfluorodecalin-filled poly(n-butyl-cyanoacrylate) nanocapsules. J Microencapsul 31(3):284-292

22. Miyaguchi N, Nagahiro I, Kotani K, Nakanishi H, Mori H, Osaragi T, Shimizu N (2006) Transintestinal systemic oxygenation using perfluorocarbon. Surg Today 36:262-266

23. Cho JS, Kim YD, Shin N, Lee CH, Cho S, Jheon S (2013) Effects of transpleural perfusion with oxygenated perfluorocarbon in a rat model of acute lung injury. Exp Lung Res 39:32-38

24. Overbeck MC, Pranikoff T, Yadao CM, Hirschl RB (1996) Efficacy of perfluorocarbon partial liquid ventilation in a large animal model of acute respiratory failure. Crit Care Med 24:1208-1214

25. Castro Cl, Briceno JC (2010) Perfluorocarbon-based oxygen carriers: review of products and trials. Artif Organs 34(8):622-634

26. Kheir JN, Scharp LA, Borden MA, Swanson EJ, Loxley A, Reese JH, Black KJ, Velazquez LA, Thomson LM, Walsh BK, Mullen KE, Graham DA, Lawlor MW, Brugnara C, Bell DC, McGowan FX Jr (2012) Oxygen gas-filled microparticles provide intravenous oxygen delivery. Sci Transl Med 4: 140ra88. doi:10.1126/scitranslmed.3003679

27. Feshitan JA, Legband ND, Borden MA, Terry BS (2014) Systemic oxygen delivery by peritoneal perfusion of oxygen microbubbles. Biomaterials 35(9):2600-2606

28. Legband ND, Feshitan JA, Borden MA, Terry BS (2015) Evaluation of peritoneal microbubble oxygenation therapy in a rabbit model of hypoxemia. IEEE Trans Biomed Eng 62(5):1376-1382

29. Lachmann B, Robertson B, Vogel J (1980) In vivo lung lavage as an experimental model of the respiratory distress syndrome. Acta Anaesthesiol Scand 24:231-236

30. Barr J, Livne A, Lushkov G, Vinograd I, Efrati Y, Ballin A, Lahat E, Eshel G (1994) Peritoneal ventilation: an animal model of extrapulmonary ventilation in experimental adult respiratory distress syndrome. Pediatr Res 35(6):682-684

\section{Submit your manuscript to a SpringerOpen ${ }^{\circ}$ journal and benefit from:}

- Convenient online submission

- Rigorous peer review

- Immediate publication on acceptance

- Open access: articles freely available online

- High visibility within the field

- Retaining the copyright to your article 